Ivana Ilić ${ }^{1}$

University of Niš, Faculty of Economics Niš

Anđelija Nikolić

University of Niš, Faculty of Economics Niš
SCIENTIFIC REVIEW ARTICLE

doi:10.5937/ekonomika1801037I

Received December, 05, 2017

Accepted: February, 21, 2018

\title{
IMPLICATIONS OF MODERN TECHNOLOGY DEVELOPMENT FOR THE TOURISM SECTOR OF THE REPUBLIC OF SERBIA
}

\begin{abstract}
Tourism is often defined as an economic sector that deals with innovation and production of tourism products and services. It is a very complex economic sector, since tourism products and stakeholders are constantly changing due to changing external forces. Therefore, development and progress of information and communication technology have had an enormous impact on tourism as well as on other sectors of the economy associated with it. Over the years, the use of modern technology in tourism has been expanded to provide a wider range of products and services to tourists all over the world, and is a key determinant of competitiveness in this sector. The subject of this paper is a look at the implications of modern technology for the tourism sector of the Republic of Serbia and the ways in which it contributes to increasing competitiveness. The analysis relies on the World Economic Forum methodology for the presentation of competitiveness of the travel and tourism sector, namely the Travel and Tourism Competitiveness Index. The aim of the paper is to examine the degree of contribution of ICT readiness pillar to the competitiveness of the tourism sector in the Republic of Serbia.
\end{abstract}

Key words: tourism, information and communication technology, competitiveness

JEL classification: Z32, D83, L86

\section{ИМПЛИКАЦИЈЕ РАЗВОЈА САВРЕМЕНИХ ТЕХНОЛОГИЈА НА СЕКТОР ТУРИЗМА РЕПУБЛИКЕ СРБИЈЕ}

\begin{abstract}
Апстракт
Туризам се често дефинише као сектор привреде који се бави иновирањем и производюом туристичких производа и услуга. Изузетно је сложен сектор привреде с обзиром на то да се туристички производи и актери стално мењају због промена спољашьих снага. Стога је развој и напредак информачино комуникачионе технологије имао огроман утииај на туризам као и на остале секторе привреде повезане са юим. Током година, употреба савремених технологија у туризму је унапређи-
\end{abstract}

\footnotetext{
1 ivanica1404@yahoo.com

22andja.niko@gmail.com
} 
вана за прижање што ширег дијапазона производа и услуга туристима широм света и кључна је детерминанта конкурентности у овом сектору. Предмет овог рада јесте сагледавање импликаиија које савремене технологије оставрују н асектор туризма Републике Србије и начина на који доприносе повећаюу конкурентности. За анализу у раду коришћена је методологија Светског економског форума за приказивање конкурентности сектора путовања и туризма тачније Индекс конкурентности путоваьа и туризма.Циљ рада је испитати степен доприноса пилара спремност информачионо комуникачионе технологије (ИЦТ спремност) на конкурентност сектора туризма у Републици Србији.

Кључне речи: туризам, информащионокомуникационе технологије, конкурентност

\section{Introduction}

Tourism industry has for decades recorded continuous expansion and growth. The next two decades can expect further positive growth. According to World Tourism Organization (UNWTO) estimates, tourism is the second largest industry in the world, which has for many years recorded constant positive growth, and participates in world GDP with 9.8\% $(7.2$ billion USD). The share of tourism in world exports of goods and services amounts to $7 \%$ (1.5 trillion USD), while in many developing countries tourism is ranked as the main export sector. At the same time, it employs about 284 million people, i.e. 1 out of 11 jobs is in the tourism sector. That tourism is on the rise around the world is seen in the change from 25 million tourists in 1950 to 1186 million tourists in 2015 (UNWTO, 2016)

Tourism sector will grow by $3.3 \%$ annually in the future (2010-2030), and the average annual growth rate of tourism consumption will be around $11 \%$. This projected growth rate for the period of 2010-2030 represents an increase of about 43 million international tourist arrivals on average annually. By comparison, to indicate that this is a positive growth trend, it should be emphasized that the average increase in international tourist arrivals amounted to about 28 million annually in the period 1995-2010. Europe, one of the most visited regions in the world, in the future will represent the most important place in the world tourism with a share of $41 \%$ in the total number of arrivals of international tourists (UNWTO, 2011). Serbia, although in the center of the growing tourism market, according to the Travel and Tourism Competitiveness Index (TTCI), is ranked $95^{\text {th }}$ out of 136 countries in the world in 2017., while in Europe it is in an unenviable $35^{\text {th }}$ place, pointing to the low level of competitiveness of our country for tourists worldwide (WEF,2017).

Competitiveness of the tourism sector of the Republic of Serbia and its recognizability among foreign tourists on the world destination map is closely related to the development and application of modern technology in tourism. There is a need to follow the trends in the constantly changing tourism industry, and to better and clearer understand tourists' demands. Innovation and application of advanced technology are not only a factor of competitiveness, but also a factor of survival, growth, and development on an extremely turbulent tourism market. The subject of this paper is a look at the implications of contemporary technology for the tourism sector of the Republic of Serbia and the ways in which it contributes to increasing competitiveness. Using the 
methodology of the World Economic Forum, i.e. Travel and Tourism Competitiveness Index, the aim of the paper is to examine the degree of contribution of ICT readiness pillar to the competitiveness of the tourism sector in the Republic of Serbia.

\section{Review of literature}

In order to highlight the essence of competitiveness in the field of tourism, the concept of tourism should first be taken into consideration, taking into account the fact that, as a phenomenon, it depends on a very wide range of factors and significantly influences the direction of the overall development of space and society in general. Tourism is a very complex economic sector, whose development has a crucial impact on the progress and prosperity of a national economy. Tourism, as an economic sector, is seen as an alternative form of economic activity, and should be viewed as a component of a large series of development initiatives within each economic system. In addition, this does not strictly mean that tourism cannot be the main source of income and jobs in a society, but that its influence and role over time vary (Chou, 2013,p.227).

Over the past years, tourism has given significant dynamics to the economy at the global level, as it is traditionally a very innovative industry (Hjalager, 2010,p.3). Tourism is a global growth industry, but for more than five decades it has been spurred by the influence of many factors. Factors that stimulate this growth are related to the level of income and wealth, changes in lifestyles and tourist values, increased leisure time, education, information and communication technology, improvement of general and tourist infrastructure, as well as destination marketing and promotion (Matias et al., 2007,p.4). Tourism is an important stimulus for economic development, especially for less developed countries like ours. Therefore, it has become one of the largest economic sectors in the world (Jovanović, Ilić, 2017,p.540).

With the increasing information in the present, information and communication technology has found a role in a large number of industries, including tourism. Since tourism is one of the most dominant industries with a large amount of money, information transfer, as well as tools and mechanisms for managing information, need to be of very high standard and quality (Ubavić, 2015, p.164). The development of modern information technology, especially during the last decades, has caused a revolutionary turn in all segments of promotion and functioning of the tourism sector. Over the years, tourism industry has developed significantly along with the development of new technology. The information revolution that permeates all sectors of the economy in terms of business has quickly entered the tourism sector, which sees this process as the best opportunity for maintaining or improving competitive position, as the condition for survival on the market (Brdar, 2015).

At a global level, the application of modern information and communication technology (ICT) has changed the way of doing business in tourism and the realization of its activities. ICT has globally transformed tourism and offered a range of new development opportunities. Products related to tourism can increase the globalization of the tourism industry in areas such as hotels, restaurants, travel agencies, or tour operators. Therefore, the use of ICT has the potential to turn markets from local to global, while in times of crisis it can contribute to better positioning on the tourism market where the number of competitors increases 
daily (Aramendia-Muneta, Ollo-Lopez, 2013). The role of information and communication technology will be increasingly significant in terms of overcoming differences in time and space, which exist among different and widely distributed stakeholders in the process of creating and delivering tourism products and services.

The spread of ICT has a major impact on ensuring sustainable and globally oriented tourism development, primarily in less developed areas (UNCTAD, 2004). In addition, ICT and social media give special opportunities to developing countries to catch up with contemporary trends and act more efficiently on the market, without large financial resources, as well as a chance for inaccessible destinations to communicate with the tourism market (Tourism Development Strategy of the Republic of Serbia for the period 20162025 , p.20). With the help of ICT, many tourism related activities are performed, such as: direct contact with clients and partners (booking, check-in/check-out, payment), office work (accounting, payroll, staff management, marketing), entertainment and services for clients, communication with customers and partners, market research, crisis response and management, flexible and dynamic pricing through revenue management, product differentiation and personalization, control of performance indicators, construction of feedback mechanisms, business process and staff management, and others.

The dynamic development of information technology has significantly changed communication in tourism; it being the key determinant of competitiveness, while a wide range of technological achievements are driving the evolution (Milićević et al., 2013,p.2). Communication in tourism used to come down only to personal contacts between tourists and service providers. Much has changed until today, so services are available 24 hours a day for 7 days a week all year round and are not limited to working hours only. The creation of tourism online portals has completely transformed all activities related to the provision of services to tourists, since these portals are successful in effectively organizing and distributing all tourists' demands and tourism industry offers (Wahab, 2017).

Along with the change of tourism communication using ICT, computerized reservation systems were developed in the nineteen-seventies, global distribution systems in the eighties, and the Internet in the nineties, which completely changed the practice of doing business in tourism. Apart from the implications for changing the structure of business in the tourism sector, the development of ICT has also affected the perception of tourists through the strengthening of interaction links, whereby ICT has a leading role in the exchange of information, knowledge, products, and services (Marković, 2008,p.136). At the same time, ICT has become a support to many critical functions in tourism, contributing to significant innovation in this sector.

A computerized reservation system first appeared in airline companies. CRS (Computer Reservation System) is a computerized system, used to store and manage information as well as to manage travel-related transactions. Although it originated in airline companies, CRS later expanded to hotel industry, rent-a-car, and other tourism branches. Large CRS operations that book and sell tickets for multiple airline companies are within GDS (Global Distribution System), a network where companies perform operations in terms of automatic transactions between the third party (service provider) and booking agents (travel agencies) with the aim of providing tourist services. The hotel business uses exclusively CRS, whose main functionalities are: reservations - individual, group, business, free rooms, price, deposit handling, blocking of rooms, change/cancellation of reservations, possibility of booking transportation, restaurants, activities, and the like (Njeguš, 2007, p.132). 
More and more services provided to tourists are based on the use of the Internet as the main communication channel, which allows simultaneous reduction in operating costs and increased number of clients. In practice, this means that tourists have the opportunity to communicate directly with the ultimate tourism service providers, and are able to identify, satisfy, and even change the requirements for tourism products and services, and, on the other hand, the service provider can more effectively meet the increasingly complex demands of their clients (tourists) (Spasić, 2007, p.45). Tourism and travel, in a large number of studies, fall into the main categories of products/services that are purchased online (Kim et al., 2011, p.259).

In 2008, around $24 \%$ of Internet users around the world used the Internet to book airline tickets (Nielsen, 2008 ). A survey conducted in 2013 found that in 2012 over 88\% of Americans used the Internet to plan and book their travel (Choe, Fesenmaier, 2014, p.428). According to a survey conducted by Google in 2014 , for $56 \%$ of tourists, the Internet is the source of travel ideas, and as many as $74 \%$ of tourists travelling for private purposes use the Internet to organize travel (Google, 2014). In addition, 85\% of tourists search the Internet for a potential destination, and average tourists make even 55 online searches before choosing a place to book (UK Essays, 2015).

Fast ICT growth makes it easy for tourists to access valuable information and at the same time improve the experience of tourists (Buhalis, Law, 2008; Neuhofer, Buhalis, 2012). Because of this, modern business environment in tourism, but also in other branches of the economy, must be in line with the potentials provided by new ICT (Van Limburg, 2012). Information and communication technology is considered a powerful driver for the development of the tourism sector of any economy, and has the potential to build a yieldbased tourism industry (Deuchar, 2012). It has been proven that ICT greatly affects the reduction of operating costs and allows small enterprises to compete internationally (Arker, 2010). It should be noted that the application of ICT in tourism encourages innovation in this sector and creates a constant avalanche of novelties for both businesses and tourists.

Figure 1 A display of the connection between ICT readiness and tourism revenues

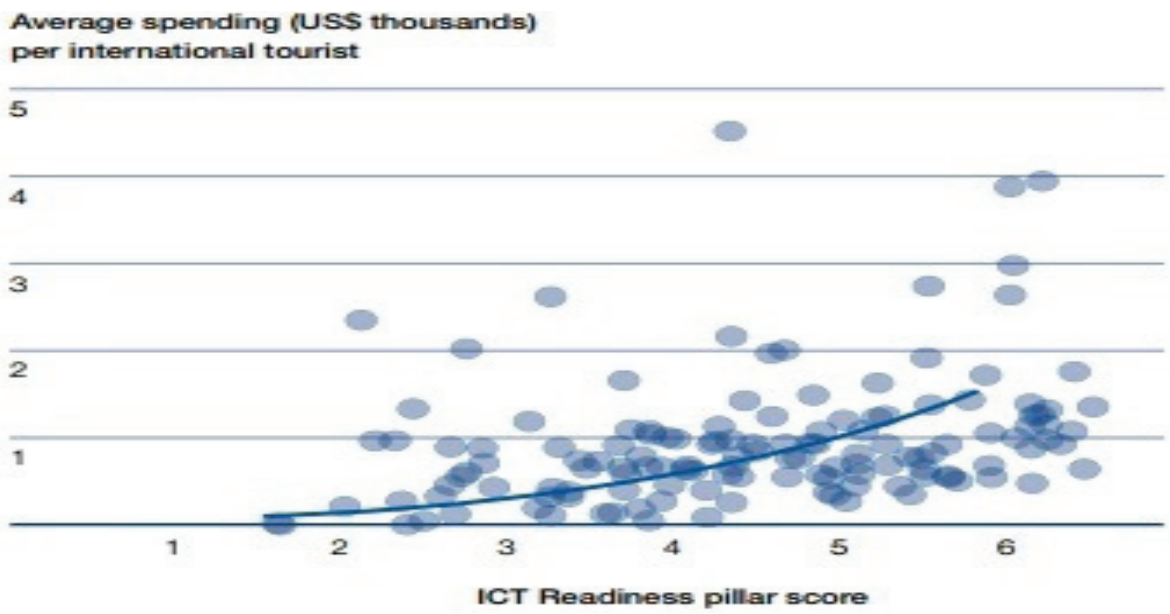

Source: WEF (2017) The Travel and tourism competitiveness report 2017,http://www3. weforum.org/docs/WEF_TTCR_2017_web_0401.pdf 
Considering the impact of ICT on the competitiveness of the tourism sector, some authors consider ICT as the key factor of competitiveness, as it reduces transactions and operating costs (Buhalis, Kaldis, 2008). On the other hand, there is a view that there is no direct positive link between the application of ICT and competitiveness (Mihalic et al., 2015). What is more, some researchers claim that competitiveness will improve only with new innovation, accompanied by widespread use of technology (Blake et al., 2006). In addition, ICT readiness directly correlates with the amount of value that tourism can generate (Figure 1) (WEF, 2017). ICT is becoming a key determinant of competitiveness and productivity in tourism, enabling it to more easily increase its market share and increase its capacity to launch innovation.

Tourism that integrates ICT into different aspects of its functioning can be called e-tourism and its trends can be tracked in Table 1 (Buhalis, O'Connor, 2005). Buhalis defines e-tourism as an application of ICT in tourism, and states that e-tourism combines three separate disciplines: business management, information systems and information management, and tourism (Buhalis, 2011). Specific e-tourism activities presuppose the existence of a larger number of participants interested in performing tourism activities in a virtual space through a specialized portal. E-tourism determines the competitiveness of tourism companies using the advantages of the intranet to reorganize internal processes within a tourism company, extranet to conduct transactions with reliable business partners, and the Internet for interaction with all interested clients.

Table 1. ICT enabled eTourism trends

\begin{tabular}{|c|c|c|c|}
\hline \multicolumn{4}{|c|}{ eTourism TRENDS } \\
\hline $\begin{array}{c}\text { Consumer-customer } \\
\text { centric }\end{array}$ & Company - profi & ability driven & $\begin{array}{c}\text { Distribution- } \\
\text { partnership enabled }\end{array}$ \\
\hline $\begin{array}{ll}\text { - } & \text { Personalization } \\
\text { - } & \text { Location/context/ } \\
\text { mood aware } \\
\text { - } & \text { Proactive/anticipatory } \\
\text { - } & \text { constive/adaptive to } \\
\text { - } & \text { System integrated } \\
\text { Satisfaction driven }\end{array}$ & \begin{tabular}{ll}
\multicolumn{2}{l}{ Revenue } \\
- & Expansion of \\
& markets and \\
& operations \\
- & Marketing and \\
& promotion \\
- & Direct distribution \\
- & Yield management \\
- & Extensive \\
& distribution \\
strategy
\end{tabular} & $\begin{array}{ll}\text { Cost } \\
\text { - } & \text { Internal } \\
& \text { integration } \\
\text { - } & \text { Reduction of } \\
& \text { intermediation } \\
\text { - } & \text { Intelligent } \\
& \text { procurement }\end{array}$ & $\begin{array}{ll}\text { - } & \text { Virtual } \\
\text { - } & \text { organizations } \\
\text { - } & \text { Interoperability } \\
& \text { Developing a } \\
\text { value system }\end{array}$ \\
\hline
\end{tabular}

Source: Buhalis, O’Connor (2006) Tourism management dynamics: Trends, management and tools

ICT has a profound impact on e-tourism, which is reflected in the digitization of all processes and value chain in travel and tourism, hospitality, and hotel management. Tactically, e-tourism allows all companies to manage their business and do e-commerce. Strategically, e-tourism revolutionizes business processes, the entire value chain, as well as strategic relationships among the interested parties. Tourism companies need to increasingly use ICT in the development of a customer (tourist)-oriented strategy, for profitability and possible partnerships that ultimately lead to a better competitive position. 
Thus, electronic mediators have had a great role in the application of modern information technology, and, through the influence of technology, linked tourism industry and clients (tourists) at the global level, thus facilitating distribution. In recent decades, tourist activity has been increasingly shaped by comparing prices and combining technology. New mobile applications continuously develop, offering a wide range of opportunities, social networks get consolidated within a more transparent market, while changes in the value chain concept create new business models. In short, changes are becoming more and more apparent and constant, just like the opportunities created by the application of new information and communication technology in the tourism sector.

\section{Application of modern technology in tourism in the Republic of Serbia}

Like most European countries, Serbia has great potential for the development of tourism, which is the driving force for some other industries, such as transport, food and processing industry, construction and consumer goods industries. The improvement of the tourism sector in the Republic of Serbia is considered one of the development priorities. The Republic of Serbia has adopted a tourism development strategy for the period until 2025, which aims to approach tourism in a systemic way, striving towards sustainable economic, ecological, and social development of tourism, strengthening the competitiveness of the tourism economy and related activities, increasing direct and total share of the tourism sector in GDP and the number of employees, and improving the overall image of the Republic of Serbia in the region, Europe, and the world (Tourism Development Strategy of the Republic of Serbia for the period 2016-2025, p.2).

According to the 2015 data, the total share of the tourism sector in GDP of the Republic of Serbia is $6.4 \%$, while direct share is $2.2 \%$. Tourism and hospitality together count about 30,000 direct employees, and there are about 157,000 newly employed in tourism and related activities. The total number of tourists in 2015 was 2,437,000. Of this number, there were 1,305,000 domestic tourists, which is by $12.2 \%$ more than in 2014 , while the number of foreign tourists who visited our country was $1,132,000$, and was higher by $10.1 \%$ compared to 2014 (Statistical Yearbook of the Republic of Serbia, 2016).

The application of information and communication technology has significantly changed the structure and principles of doing business in the tourism sector of Serbia. Wisely using ICT can be an innovative strategic tool for tourism companies in our country, which will help them, become more competitive and improve their business and market position both domestically and internationally. Modern ICT accelerates the process of linking tourist offer and tourist demand on the market, giving a completely new dimension to the distribution of package holidays and better recognition and visibility of Serbian tourist offer on the global market. With the increased level of tourist information and more detailed presentation of Serbia's tourist potential through electronic channels that become available by implementing ICT, it is to be expected that the number of tourists as well as revenues from tourism will increase. Modern ICT services and applications, which make it easier for tourism companies to sell their products and services on the Internet, open the possibility for a more expansive development of e-tourism, which is an integral part of the electronic trade in Serbia. 
The problem that has arisen in the Serbian tourism sector is the poor political and economic situation, which caused a delay in adopting ICT, which proved to be a very significant aspect of the development of this sector of the economy. Over time, as the problem disappeared, the Internet became more and more accessible to all participants in the business world, as well as to the tourist companies in Serbia, which used it to develop presentations of tourist destinations, representing the whole country, certain regions, and certain sites. The web portal is used to present the tourist potential of Serbia, attract domestic and foreign tourists, and provide useful information. The most famous domestic web portals are Srbija. travel, Visit Serbia.org, Serbia TouristGuide.com, Serbia.com, and BelGuest.rs.

Tourism Development Strategy of the Republic of Serbia for the period 20162025 presents SWOT analysis, which, as a weakness of the tourism sector, identifies the inadequacy of domestic Internet platforms and ICT applications for the promotion of tourist destinations, virtual guides, and applications. In order to overcome these weaknesses and make the vision of tourism development come true, one of the main growth drivers in the future is the improvement of ICT system of promotion and booking and raise the efficiency of capacity commercialization. The fact that only $5 \%$ of Serbian citizens use the Internet to reserve a trip, while most do it alone or through a travel agency, confirms the necessity of focusing efforts on this. In order to successfully implement the strategy vision, as well as for the desired market positioning, there should be changes in the functioning of the tourist organization of Serbia, in terms of providing a unique information and communication system in tourism and the application of modern ICT tools. The European Union supports and finances numerous activities and programs in the tourism sector of Serbia, in order to facilitate strategy implementation, and one of the priority activities is the development of tourism-related ICT products.

\section{Results and discussion}

Tourism is a complex industry, so destination competitiveness is the result of many factors (Vanhove 2006). Competitiveness of the destination is usually analyzed using the relevant models. The most frequently used model was developed by the World Economic Forum under the Travel and Tourism Competitiveness Index. The Travel and Tourism Competitiveness index (TTCI - Travel and Tourism Competitiveness Index) was developed to measure the global competitiveness of the travel and tourism sector among different countries. This index aims to measure the attractive factors and policies for the development of the travel and tourism sector in various countries. In the past, the TTCI structure consisted of three main subindices with 13 pillars analyzing about 75 indicators. Since 2015, the TTCI methodology has changed, in terms of the number of indicators analysed, in order to present a more realistic picture of the travel and tourism competitiveness. The new 90 indicators are classified into 4 main subindices (1. Enabling environment; 2.Travel and tourism policy and enabling conditions; 3.Infrastructure; and 4.Natural and cultural resources) and 14 pillars (WEF, 2015).

The Enabling environmentsubindex includes factors that are directly related to economic growth and are important for business development, including but not limited to travel and tourism sector. Within this subindex there are the following pillars: 1 . Business environment; 2. Safety and security; 3. Health and hygiene; 4. Human resources 
and the labor market, and 5. ICT readiness. The new subindex, Travel and tourism policy and enabling conditions, is made of pillars that are more specific for the tourism and travel sector. These are: 1. Prioritization of the tourism and travel sector; 2 . International openness; 3. Price competitiveness; and 4. Environmental sustainability. More precisely, pillars refer to direct measures for the realization of tourism and travel policy, factors that directly affect the decisions of tourists to choose a destination, and natural capital on which a large part of the tourism industry is based, and which needs to be preserved. The separation of infrastructure as a separate subindex points to its driving force for the tourism sector. The pillars in this subindex are: 1 . Air traffic infrastructure; 2 . Road and port infrastructure; and 3. Infrastructure for the provision of tourist services necessary for the smooth development of tourism and better competitiveness. The role of the last subindex, Natural and cultural resources, is particularly emphasized, whose structure is precisely composed of two pillars 1 . Natural resources, and 2. Cultural resources and tourism business. In addition to business and personal reasons, cultural and natural resources are probably the main reason for visiting a destination. There is a tendency to give national importance to these two pillars, and develop policies for their protection and promotion (WEF, 2015).

Figure 2 Subindices of the Travel and Tourism Competitiveness Index

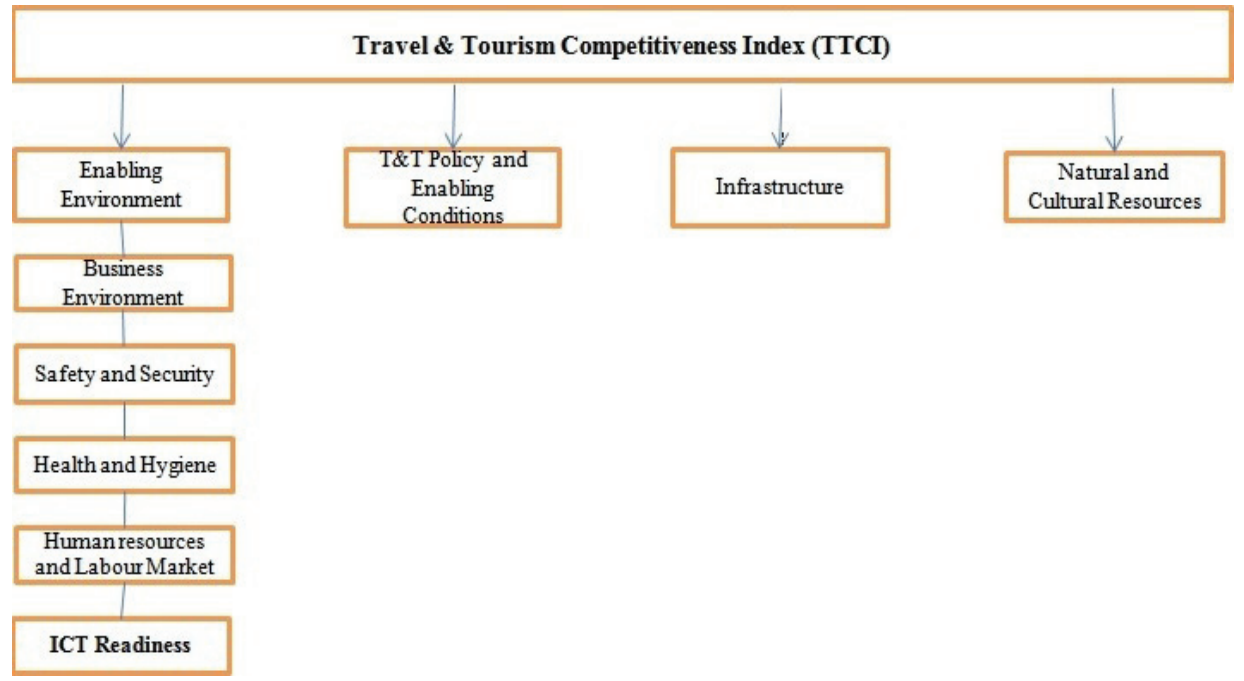

Source: World Economic Forum (2015) The Travel and Tourism Competitiveness Report 2015, Geneva, Switzerland.

The focus of this paper is on ICT readiness pillar (formerly referred to as ICT infrastructure), which is extremely important for all sectors of the economy and is considered part of the general environment for the development of tourism and travel. Internet services and business operations are increasingly important for travel and tourism, while the Internet is used for travel planning and accommodation booking. This pillar measures the rate of ICT penetration (Internet and telephone lines), which reflects social networking activities and the use of the Internet by companies in their business 
transactions (WEF, 2017). Therefore, the eight components of this pillar measure not only the existence of modern infrastructure (mobile network coverage, quality of electricity supply), but also the ability of companies and individuals to use and provide online services. The inclusion of ICT readiness in TTCI is the result of years of research that has shown that the key to the success of tourism is precisely in connectivity, both social and technological. Social cohesion is closely intertwined with technology in terms of the Internet that connects people all over the world and has enabled their constant contact.

In accordance with the subject of this paper, to examine the implications of modern technology for the tourism sector of the Republic of Serbia and the way in which it contributes to increasing competitiveness, the travel and tourism competitiveness index (TTCI) is analyzed more precisely, i.e. the pillar which closely assesses the competitiveness of ICT readiness (infrastructure) in our country. The focus is on all available World Economic Forum reports on TTCI covering the time interval from 2007 to 2017, following the trend of ICT readiness pillar for the Republic of Serbia. According to the latest report of the World Economic Forum for 2017 on the travel and tourism sector competitiveness in countries around the world, Serbia is ranked $95^{\text {th }}$ of 136 analyzed countries. The total value of the travel and tourism competitiveness index is 3.4 , increasing by 0.1 compared to the previous year, but not resulting in moving forward in the rankings. In the previous year, Serbia held the same $95^{\text {th }}$ position in the list. Observing the index as a whole, one can note a slight increase in almost all pillars of travel and tourism competitiveness included in the index structure.

Graph 1 Trends in the value of the Competitiveness Index for Serbia in the period 2007-2017

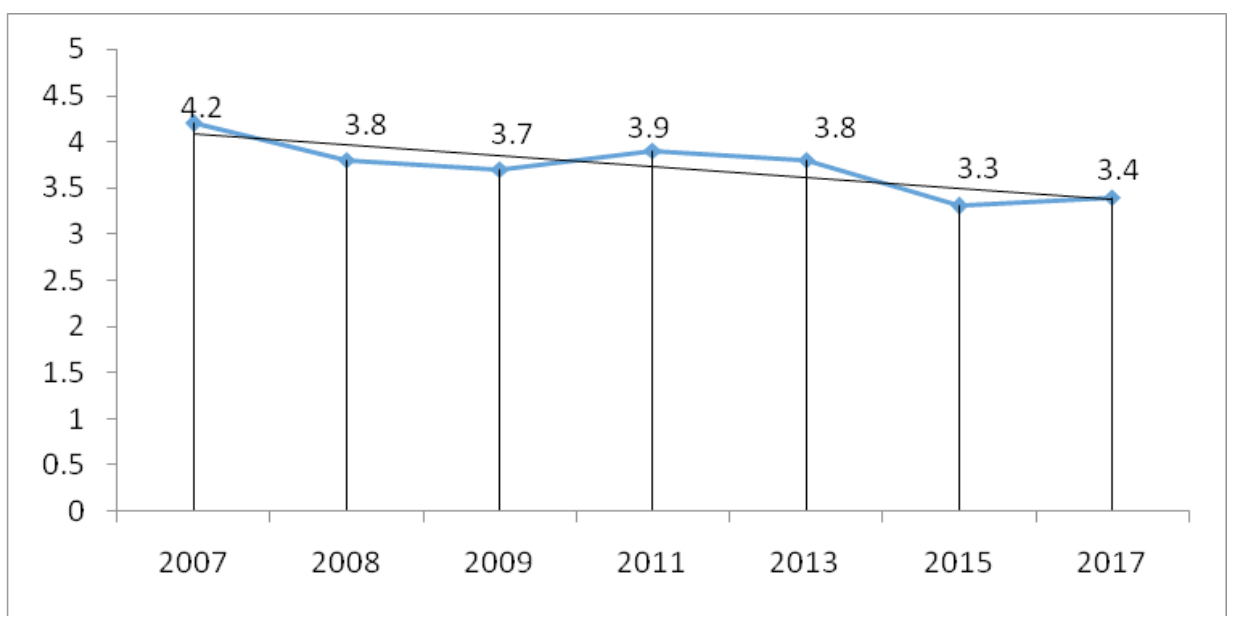

Source: WEF (2007, 2008, 2009, 2011, 2013, 2015, 2017)

Graph 1 shows the trend of TTCI values in the period from 2007 to 2017 and a declining trend, but with great instability in terms of significant oscillations in a short period of time. Major oscillations are mentioned because a change of only 0.01 can result in a significant move in the rankings, especially in the part of the list where Serbia is. There is a big difference in the value of TTCI in 2007, when Serbia and Montenegro were analyzed as one country, and in 2017 , when the value slightly increased compared 
to the previous year (2015), when TTCI was the lowest since it started being calculated. When it comes to the best ranked economy by the TTCI value, in this year's report Spain for the second time in a row occupies the first place with the highest TTCI value (5.43), while Yemen is in the last position in the list with the lowest TTCI (2.44). The second most competitive economy in terms of travel and tourism is France, while Germany is in the third position as in the previous report (WEF, 2017).

Table 2 Rank and value of TTCI and ICT readiness pillar for Serbia in the period 2007-2017

\begin{tabular}{|c|l|r|r|r|r|r|r|r|}
\hline \multirow{3}{*}{ Serbia } & Year & $\mathbf{2 0 0 7}$ & $\mathbf{2 0 0 8}$ & $\mathbf{2 0 0 9}$ & $\mathbf{2 0 1 1}$ & $\mathbf{2 0 1 3}$ & $\mathbf{2 0 1 5}$ & $\mathbf{2 0 1 7}$ \\
\cline { 2 - 8 } & $\begin{array}{l}\text { Number of } \\
\text { country }\end{array}$ & 124 & 130 & 133 & 139 & 140 & 141 & 136 \\
\hline \multirow{3}{*}{ TTCI } & Rank & 61 & 78 & 88 & 82 & 89 & 95 & 95 \\
\cline { 2 - 8 } & Score & 4.2 & 3.8 & 3.7 & 3.9 & 3.8 & 3.3 & 3.4 \\
\hline \multirow{3}{*}{ ICT readiness } & Rank & 46 & 57 & 63 & 62 & 49 & 56 & 57 \\
\cline { 2 - 8 } & Score & 3.3 & 2.8 & 2.9 & 3.3 & 3.9 & 4.45 & 4.8 \\
\hline
\end{tabular}

Source: WEF $(2007,2008,2009,2011,2013,2015,2017)$

Unlike the value of TTCI, which gradually declines over time, and, thus, the ranking of Serbia in the world list, the value of ICT readiness pillar has been steadily increasing over the years. The value itself increased by more than one point, but, depending on the number of countries analyzed, the ranking oscillated from $46^{\text {th }}$ to $63^{\text {rd }}$ position in the list (Table 2). The increasing penetration of modern technology and its implementation into companies' operations, as well as everyday application by individuals, made Serbia more competitive with ICT readiness and thus recognizable for tourists around the world. In this respect, the Tourism Development Strategy of the Republic of Serbia for the period 2016-2025 gives priority to the development of ICT tools in tourism. Hong Kong is the most competitive economy by TTCI in terms of ICT readiness in 2017. Germany and Switzerland follow it, while the lowest level of application of modern technology is present in Burundi.

Table 3 Value of ICT readiness pillar components for Serbia in the period 2013-2017

\begin{tabular}{|c|c|c|c|c|c|c|c|c|}
\hline \multirow{2}{*}{ Structure of ICT readiness } & \multicolumn{2}{|c|}{2013} & \multirow{2}{*}{ Change } & \multicolumn{2}{|c|}{2015} & \multirow{2}{*}{ Change } & \multicolumn{2}{|c|}{2017} \\
\hline & Rank & Score & & Rank & Score & & Rank & Score \\
\hline ICT use for biz-to-biz transactions & 117 & 4.2 & 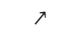 & 88 & 4.5 & $\mathrm{I}$ & 95 & 4.4 \\
\hline Internet use for biz-to-consumer transactions & 122 & 3.5 & $\lambda$ & 95 & 4 & $\lambda$ & 89 & 4.1 \\
\hline Internet users $\%$ population & 67 & 42.2 & 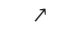 & 65 & 51.5 & 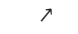 & 56 & 65.3 \\
\hline $\begin{array}{l}\text { Fixed-broadband Internet subscriptions } / 100 \\
\text { pop. }\end{array}$ & 30 & 37.3 & $\searrow$ & 50 & 14.2 & $\lambda$ & 51 & 17.4 \\
\hline $\begin{array}{l}\text { Mobile-cellular telephone subscriptions } / 100 \\
\text { pop. }\end{array}$ & 37 & 125.4 & $\searrow$ & 56 & 119.4 & $\lambda$ & 60 & 120.5 \\
\hline Mobile-broadband subscriptions /100 pop. & 37 & 34.5 & $\lambda$ & 39 & 53.7 & $\lambda$ & 40 & 71.8 \\
\hline Mobile network coverage \% pop. & & & & 53 & 99.7 & $\lambda$ & 50 & 99.8 \\
\hline Quality of electricity supply & & & & 75 & 4.3 & $\lambda$ & 70 & 4.8 \\
\hline
\end{tabular}

Source: WEF $(2013,2015,2017)$ 
ICT readiness pillar is composed of eight components: ICT use for B2B transactions, Internet use for B2C transactions, number of Internet users, number of fixed broadband Internet subscribers, number of mobile phone subscribers, number of mobile broadband network subscribers, mobile network coverage, and quality of electricity supply (WEF, 2017). Based on the three-year period shown in Table 3, changes in the value of ICT readiness pillar point to a constant growth trend in most of its components. The highest percentage change in growth was achieved with the Internet use for B2C transactions and the quality of electricity supply, followed by the number of Internet users and the number of mobile broadband subscribers, in relation to their values in 2013 and 2017. Oscillatory trend with a slight decrease in value in this period was characteristic for components of ICT use for B2B transactions, number of fixed broadband Internet subscribers, and number of mobile phone subscribers. In addition to the value of the components, the ranking of Serbia in the world list also changed. According to the ranking of ICT readiness pillar components, Serbia is in terms of the number of Internet users, number of fixed broadband Internet subscribers, number of mobile broadband subscribers, mobile network coverage, and number of mobile subscribers in the first half of the world list for 2017.

Table 4 TTCI and ICT readiness pillar correlation matrix for Serbia in the period 2007-2017

\begin{tabular}{|l|l|r|r|}
\hline \multicolumn{2}{|c|}{} & TTCI & ICT readiness \\
\hline \multirow{4}{*}{ TTCI } & Pearson Correlation & 1 & .434 \\
\cline { 2 - 4 } & Sig. (2-tailed) & & .033 \\
\cline { 2 - 4 } & $\mathrm{N}$ & 7 & 7 \\
\hline \multirow{5}{*}{ ICT readiness } & Pearson Correlation & .434 & 1 \\
\cline { 2 - 4 } & Sig. (2-tailed) & .033 & 7 \\
\cline { 2 - 4 } & $\mathrm{N}$ & 7 & \\
\hline
\end{tabular}

Source: Authors' own calculation based on WEF data

Using the statistical method of correlation analysis, the relationship between TTCI and ICT readiness pillar from 2007 to 2017 was examined. By calculating the Pearson coefficient for the two variables in the analyzed time period, it is concluded that there is a direct medium strong correlation between them. The Pearson coefficient value is 0.43 , with a statistically significant level of 0.03 , indicating that there is a direct quantitative agreement between the variables. It should be noted that the change in the value of ICT readiness pillar can contribute to changing the values of the travel and tourism competitiveness index, but it does not play a key role in the formation of the total value of the index.

The use of ICT is a relevant opportunity for the growth and strengthening of the local tourism industry, as well as for the development of the destination economy as a whole. In particular, ICT has the potential to increase the revenues of a particular destination and thus affect the financing of economic and social development (UNCTAD, 2005). ICT power is primarily reflected in the development and strengthening of local tourism and entrepreneurial activities related to tourism, the development of the right tourist offer relying on the exploitation of local production and tradition, and facilitating 
direct promotion and commercialization of local tourism offer on international markets, with reduction of dependence on large foreign intermediaries (Petti, Passiante, 2009, p.50). Serbia has recognized all the benefits of ICT application in tourism and has made a number of efforts to implement it efficiently and in as many activities as possible in order to achieve better competitiveness of this sector, and, thus, higher tourism revenues. Although the quality of ICT readiness in Serbia is below the level of EU countries, it has been impressively improving over the past several years. In addition, the quality of ICT infrastructure itself does not represent a significant obstacle for the business of tourism companies in our country, since most of them are concentrated in urban areas where quality meets the high standards that enable smooth electronic business.

\section{Conclusion}

Modern technology has in many ways influenced growth and development in the tourism sector. This is confirmed by the fact that the expectations of tourists have increased significantly in terms of expecting better and well-designed services. The expectations are that in the coming years ICT will play an increasingly important role and will further develop, which will be an opportunity for the tourism industry to deal with the newly emerging changes in the environment. For tourists, the use of ICT means better-defined services that are continually improving in order to increase the level of satisfaction. The main goal of introducing ICT into the tourism sector is certainly an improvement in the provision of services that give tourists greater value for money invested in travel and tourism.

For companies in the tourism sector, it is very important to realize that, through modern information and communication technology, they can secure their existence on the market, improve communication with tourists, improve the position of their facilities, sell their tourist products/services, cooperate with other companies and sell their arrangements, increase their productivity and efficiency as well as revenue, reduce costs and improve their business. Finally, the ICT revolution has brought about significant changes in governance and business in the tourism sector, as well as the development of the electronic form of tourism - e-tourism.

The Republic of Serbia has recognized the need for more intensive implementation and exploitation of ICT in the tourism sector. The Tourism Development Strategy of the Republic of Serbia in the period up to 2025 gives one of the key priorities to investment in ICT development, improvement of ICT promotion and reservations, and raising the efficiency of commercialization of capacities. According to ICT readiness pillar, Serbia is listed in the first half of the world list of countries analyzed in 2017, and aims to continuously increase competitiveness of the tourism sector. The value of this pillar during all the analyzed years has been steadily increasing, which indicates an increasing degree of application and distribution of modern technology in the business of the Serbian tourism sector. In addition to solid ICT readiness compared to neighboring countries, Serbia has room to improve it. 


\section{References}

Arker, D. (2009). Building Strong Brands. SMQ, (6), New York. The Free Press.

Aramendia-Muneta, M. E., \&Ollo-Lopez, A. (2013). ICT Impact on tourism industry. International Journal of Management Cases, 15(2), 87-98.

Blake, A., Sinclair, M.T., \& Campos Soria, J.A. (2006). Tourism productivity: Evidence from the United Kingdom. Annals of Tourism Research, 33(4), 1099-1120.

Brdar, I. (2015). UticajglobalizacijenarazvojturizmaSrbije, UniverzitetSingidunum, departman za poslediplomskestudijeimeđunarodnusaradnju Beogradhttps:// singipedia.singidunum.ac.rs/preuzmi/41025-uticaj-globalizacije... turizma.../1096

Buhalis, D., \& O'Connor, P. (2005). Information communication technology revolutionizing tourism. Tourism Recreation Research, 30(3), 7-16.

Buhalis, D., O'Connor, P. (2006). Tourism management dynamics: Trends, management and tools, Oxford, UK: Elsevier Butterworth-Heinemann.

Buhalis, D., \&Kaldis, K. (2008). eEnabled internet distribution for small and medium sized hotels: the case of Athens. Tourism recreation research, 33(1), 67-81.

Buhalis, D., \& Law, R. (2008). Progress in information technology and tourism management: 20 years on and 10 years after the Internet The state of eTourism research. Tourism Management, 29(4), 609-623.

Buhalis, D. (2011). E-Tourism. Contemporary Tourism Reviews. (n.d.). Contemporary Tourism Reviews. Oxford: Goodfellow Publishers Limited.

Chou, M. C. (2013). Does tourism development promote economic growth in transition countries? A panel data analysis. Economic Modelling, 33, 226-232.

Choe, Y., \&F esenmaier, D. (2014). Assessing Structure of Online Channel Use by American Travellers. In Z. Xiang, \& I. Tussyadiah (Ed.), Information and Communication Technologies in Tourism. Springer International Publishing.

Deuchar, C. (2012). Small tourism enterprise network formation in rural destinations: Integrating ICT and community in Western Southland New Zealand (Doctoral Thesis). Auckland University of Technology.

Google (2014). The 2014 Traveler's Road to Decision https://storage.googleapis.com/ think/docs/2014-travelers-road-to-decision_research_studies.pdf

Hjalager, A. M. (2010). A review of innovation research in tourism.Tourism management,31(1), 1-12.

Jovanović, S., Ilić, I. (2017). Regional features of tourism and hotel industry in the Republic of Serbia, The Second International Scientific Conference - Tourism in function of development of the Republic of Serbia, University of Kragujevac, Faculty of hotel management and tourism in Vrnjačka banja, Vrnjačka banja, 538-555,

Keller, P., \& T. Bieger (Eds.), Productivity in Tourism: fundamentals and concepts for achieving growth and competitiveness (pp. 167-188). Berlin: Erich Schmidt Verlag 
Kim, M. J., Chung, N., \& Lee, C. K. (2011). The effect of perceived trust on electronic commerce: Shopping online for tourism products and services in South Korea. Tourism Management, 32(2), 256-265.

Marković, V., \&Armenski, T., (2008). Primenainformacionetehnologije u lovnomturizmu, Zbornik radova Departmana za geografiju, turizam I hotelijerstvo, br. 37, pp. 136.

Matias, A., Nijkamp, P. \& Neto, P. (2007). Advances in Modern Tourism Research: Economic Perspectives, Heidleberg, Physica-Verlag

Mihalič, T., GarbinPraničević, D., \&Arnerić, J. (2015). The changing role of ICT competitiveness: the case of the Slovenian hotel sector. Ekonomska aistraživanja, 28(1), 367-383.

Milićević, S., Podovac, M., \&Sekulić, D. (2013). Uloga i značaj informacionih tehnologija za razvoj turizmaSrbije, 13th International Conference Research and Development in Mechanical Industry RaDMI 2013, Kopaonik, Srbija

Ministry of Trade, Tourism, and Telecommunications (2016). Tourism Development Strategy of the Republic of Serbia for the period 2016 -2025., http://mtt.gov.rs/ download/3/strategija.pdf

.Neuhofer, B., \&Buhalis, D. (2012). Understanding and Managing TechnologyEnhanced Tourist experiences. 2nd Advances in Hospitality and Tourism Marketing \& Management Conference Proceedings

Nielsen, (2008). Trends in Online Shopping. Nielsen. Retrieved on 19. 12., 2016 from http://witsa.org: http://witsa.org/press/Digital_Planet_Release_final.doc

Njeguš, A.,(2007) Poslovni informacioni sistemi, Univerzitet Singidunum, Beograd

Petti, C., \&Passiante, G. (2009). Getting The Benefits Of ICTs In Tourism Destinations: Models, Strategies And Tools. Int. Arab J. e-Technol., 1(1), 46-57.

Republički zavod za statistiku Republike Srbije (2016). Statistički godišnjak Republike Srbije 2016, http://pod2.stat.gov.rs/ObjavljenePublikacije/G2016/ pdf/G20162019.pdf

Spasić, V. (2007). Uloga velikih organizatora putovanja u stvaranju globalnog turističkog proizvoda. Zbornik radova „Hotellink“. Beograd: Visoka hotelijerska škola.

Van Limburg, B. (2012). Visiting suriname, using dart to analyze a visitor's perspective in a co-creation environment. Information Technology and Tourism, 13(2): 119-132.

Vanhove, N. (2006). A Comparative Analysis of Competition Models for Tourism Destinations. In M. Kozak, L. Andreu (Eds.) Progress in Tourism Marketing, 101-114, Oxford: Elsevier

Ubavić, P. (2015). Informational resources management in tourism. Ekonomika, 61(1), 161-171.

UK Essays (2015). Impact of Technology on Tourism, https://www.ukessays.com/essays/ tourism/technology-has-significant-impact-on-the-travel-tourism-essay.php

United Nations Conference on Trade and Development (UNCTAD) (2004). UNCTAD'S eTourism Initiative, Doc. TD(XI)/BP/6), 26 April http://www. unctad.org/en/docs/tdxipbd6_en.pdf. 
United Nations Conference on Trade and Development (UNCTAD) (2005). The Information Economy Report 2005, New York and Geneva, pp. 142-186

Wahab, I., (2017). Role of Information Technology in Tourism Industry: Impact and Growth, International Journal of Innovative Research in Computer and Communication Engineering,260-263

World Economic Forum - WEF (2007,2008,2009, 2011, 2013, 2015, 2017). The Travel and Tourism Competitiveness Report, Geneva, Switzerland.

World Tourism Organization (UNWTO) (2016) UNWTO Tourism Highlights 2016 Edition, http://www.eunwto.org/doi/pdf/10.18111/9789284418145 (17.9.2017.)

World Tourism Organization (UNWTO) (2011) Tourism Towards 2030 / Global Overview, http:/www.wise.co.th/wise/Knowledge_Bank/References/Tourism/ UNWTO_Tourism_Toward_2030.pdf (6.9.2017.) 